\title{
The post-secular position and enchanted bodies
}

$\mathrm{T}^{\mathrm{h}}$ he English-American writer Zoë Heller, at the beginning of her novel The Believers (2008), cites the Italian Marxist philosopher Antonio Gramsci: 'The challenge of modernity is to live without illusions and without becoming disillusioned.' This diagnosis of modern life, given by Gramsci and elaborated in fiction by Heller, can be translated as pointing towards varying positions between secularity (even secularism), on the one hand, and (religious or political) belief and commitment on the other. This crossroads of belief and disbelief, or enchantment and disenchantment, is topical in new ways after recent revisions of secularization theories and the current revitalization of religions. Moreover, it also has bearings on how people bring together religions and bodies. The following question is of particular interest to me: in what ways can diverse religious and spiritual practices bring about and construct new kinds of enchanted embodiments within contemporary life, and what is being done with these embodiments, both by people themselves and by scholars of religion. First, I shall outline a preliminary diagnosis of the current situation, which I approach as the desire for enchanted bodies. After that I shall identify, though tentatively, three ideal types of practices by which this desire could be seen to be enacted. Finally, I shall consider some implications of this diagnosis for the study of religion today.

\section{The desire for enchanted bodies}

In their book Re-forming the Body (1997), Philip Mellor and Chris Shilling look at various formations and re-formations of bodies within Christian history and secularization. They finish the book with the following words: 'If the modern project could continue to ignore the sensual human body, other than as a resource for commercial exploitation. . ., it would continue its descent into banality. If it turns out that it cannot, then something approaching the volatility and passionate intensity which characterized medieval life may again impose itself upon large tracts of the Western world.' (Mellor \& Shilling 1997: 201.) Perhaps this prediction by Mellor and Shilling is a little 
bit overstated and romantic, and we are not exactly approaching the medieval situation today. However, if we proceed still a little while with Heller (since fiction is often an excellent heuristic device in the study of culture and all the kinds of desires that it nurtures), we can see that some sort of desire or urge (hunger, appetite) to enchant, or re-enchant (our research participants' but also the researchers') embodied lives can be observed.

In Heller's novel an atheist Jewish family in its way exemplifies and embodies the fragile conditions of those living in the 2000s. The lives of the parents of the family have been committed for forty years to stern leftist convictions and hard work for political justice. When the father of the family falls into coma and eventually dies, some unpleasant truths begin to emerge from beneath the surface. What follows is that his spouse is left bereft of meaning and purpose in life. Their three adult children have grown up in a world much too complex and compromised to be able to follow their parents' unwavering political path, and in their early midlife, they also find themselves in the face of the threat of banality and meaninglessness, all in their own ways-either as a result of the unpleasant downsides of modernity, as according to, for instance, Charles Taylor (2002), or total disillusion as according to Gramsci. Their respective ways out of this existential cul-de-sac are different from each other, taking the form of alcohol and drug abuse for the son, romance and religious commitment for the two daughters. All these choices and solutions provide some sort of sense of meaning, of destiny, in the face of modern anxieties, fragile identities and uncertain agencies. Addiction may be a relatively sad version of destiny: the addict is easily regarded merely as an object of uncontrollable forces instead of being an agent of his or her own destiny, whereas the agency in romance and religion is much more ambivalent and intriguing with regard to destiny.

Anthony Giddens (1991: 109-43) writes about fate as a notion that has lost much but not all of its hold in modernity. This is related to modernity being largely defined by the notion of risk. According to Giddens, fate has been bestowed with the sense of fortuna, as a preordained course of events, in traditional societies; in an important sense, the future has not been in the hands of humans, but gods. And this is what has changed: now people want to control their futures. Post-traditional societies are increasingly characterized by the growing awareness of many kinds of risk, and, accordingly, by elaborate risk calculations and risk-management efforts at both social and individual levels. Both groups and individuals aim at what he calls the 'colonization of the future' by various political, scientific and technological means; important examples of these means are economic calculation and medical technology. 
People today are invited to take advice and make assessments that help them navigate a risk society and control, or at least minimize most known risks, thus providing themselves with futures which are as secure as possible.

According to Giddens, fatalism in the face of the unpredictability of the future is an alternative modern ethos for those who do not want to live their lives assessing risks and possibilities and taking responsible actions on the basis of this assessment. A fatalistic person does not believe in an individual's agency in managing and directing one's life in a complex and risk-filled world, but takes a cynical or ironic laissez-faire-ethos towards it. Lenny's addiction can, perhaps, be regarded as fatalism in anticipation of his future and destiny, whereas Karla's erotic adventure and Rosa's religious conversion seem to be solutions whereby they seek to build agency and active participation, if not mastery, with regard to their lives. However, of course, this is very relative and context-specific: both love and religion can be engaged with either in a fatalistic or in a more active and intentional-strategic manner. (In fact, Karla is depicted as someone captivated, nearly against her own will, by the force of love whereas Rosa's conversion is described as a more reflective and conscious action.) Moreover, love and religion may be understood as ways of engaging with destinies precisely because they involve both passive (fatalistic) and active attitudes and stances towards life and the future.

Thus, fate or destiny has not altogether been evacuated from modernity, but has its place alongside the risk-calculating ethos. Furthermore, I would like to make a slight but important distinction between fate and destiny. On the one hand, fate is more connected to the non-human deity fortuna-the Roman goddess was sometimes depicted as blind and quite merciless towards humans. On the other hand, destiny is connected to the interaction or dialogue between fortuna (or providence, in its more Christian version) and human action. Destiny would thus be understood as a sense of direction and purpose in life that unfolds partly by means of human action.

All the above solutions portrayed by Heller through her fictional characters involve not only the thinking minds of the people in question, but also their sensing and committed bodies. Drug addiction holds the body of Lenny in a stern grip. Rosa's newly found Jewish body is dressed in a completely new way from what it used to be and it learns gestures and positions with their ever thickening religious meanings and purposes. Karla's body, in love for the first time at an adult age, learns new sensuous pleasures and lessons of itself, of the other and the world. Bodies can thus be engaged and reoriented to bring out new experiences, visions and commitments in life. They can be oriented in such ways that they very concretely bring out new futures and des- 
tinies to their bearers. Moreover, enchanted bodies are fragile attempts and orientations, surrounded by heavy structural conditions, and they are open to many possible perils towards embodied futures.

Heller depicts plausible characters and causes of events, even if they are fictional and not ethnographically documented ones in the strict sense. Moreover, many scholars of religion, especially those who study women's religious lives and women's relation to religion, report and analyze cases which are comparable with the fictional case of Rosa, who commits herself to Orthodox Judaism after having been brought up in an atheist family with only a Jewish background. To some extent Rosa reminds me of Sarah Bracke's (2008) research participants in Holland, for instance. They are youngish modern educated women who have chosen a relatively conservative version of the religion of their families; for some of them it is Christianity and for others it is Islam. In slightly similar way, Saba Mahmood (2005) investigates the puzzle of Egyptian women who piously adhere to conservative forms of Islam in their desire to construct embodied moral lives, even though there are also secular possibilities available for them in principle. Rebecca Lester's (2005) ethnographical study of a Mexican convent follows a group of postulants who consider their choice to become nuns as one possible and good way to live a woman's life in a woman's body in the midst of a modern and rapidly changing, as well as very demanding world. Jone Salomonsen's ethnography among witches in San Francisco (1999) opens up the world of feminist religious women activists who work to re-conceptualize and re-live both bodies and material environment. Joe McPherson's (2008) study of Reiki in Scotland shows how healers, most of them women, provide an alternative healing practice with an elaborate conceptualization and technique of the body.

In Finland, Johanna Ahonen is preparing her dissertation for which she has interviewed Finnish women committing themselves, their bodies and souls, to various versions of Hinduism, such as Hare Krishna or followers of Amma (see Ahonen 2006). Furthermore, some women and men (and this reminds us that this is not exclusively a woman-question even if for women the question of religion and body may be more acute) in Tuija Hovi's (2007) research have devoted their lives to charismatic Christianity. In this context one very much submits one's life to the religious community's interpretation of the Bible and God's will. One engages in daily religious practices and ritualized healing practices that enforce biblical interpretations, as well as anchoring them in bodily habits. All these contemporary enchanted bodies of women, and some men too, empowered with religious meaning and religiously legitimated agency, are something we can see and appreciate with post-secular 
eyes. But what do I mean by the terms enchanted bodies and post-secular eyes?

By using the term post-secular I do not mean to say that something has essentially or irrevocably changed after a phase of secularization in the social and symbolic world. Rather, post-secular for me principally means the somewhat more nuanced position and detailed gaze of the researcher than was possible some time ago; a position from which we can now, after a period spent in the power of the secularization narrative, focus our attention on historically and culturally varying forms of enchantment, disenchantment and reenchantment of embodied lives (see also Cannell 2010). Perhaps religious scholars are beginning to better learn their ways in a reality where people continuously use many practices to navigate between illusion and disillusion. By enchantment here I simply refer to meaning-making practices and operations that engage with other than simply empirically verifiable forces or entities that are in some sense believed and used to resource mundane or secular lives, summoned and used to make help things happen. Disenchantment and reenchantment are relative to enchantment, pointing to the fact that enchantment is always a process, and as a process, it can grow or diminish depending on context (cf. Partridge 2004). We may be living in a historical period in Western societies (after such big changes as the collapse of the Communist empire, the rapid development of information technology and intermingling of cultural impulses) that creates more space and an increased urge for the enchantment of bodies than sometime earlier when certain political and epistemological dividing lines were more solid.

The post-secular position calls attention to various practical, rhetorical and imaginary in-between spaces, where different meaning-making practices and processes in relation to enchantment can take place. Examples of these in-between spaces could be health care contexts that allow alternative practices, such as energy-healing; gym practices that combine physical exercises and spiritual meanings, or forms of popular culture such as books and films that bring different worlds together. An example of the latter would be the bestselling novel, The Lovely Bones by Alice Sebold (2009), in which a murdered girl witnesses the life of her family on earth and eventually integrates with it.

An important aspect or focus of enchantment is the body. It is very much the body that is the location of the enchantments: its parts are given new names and meanings, or bodies are practiced upon and treated with methods that construct new aspects or powers in them. In many Western countries, such as Finland, bodies are conceptualized, imagined and lived today with many 
more creative methods than they used to be. This is particularly done and talked about more publicly and openly than earlier, when issues like religious and political affiliation were strictly personal matters in Finland (cf. Bowman 1999: 2). Major religious (such as the Evangelical Lutheran Church) and scientific powers (such as Western bio-medicine) have increasingly become only two discourses and practices regulating and informing bodies among many choices and possibilities (see, e.g., McGuire 1988, Bowman 1999).

\section{Identifying three ideal types of practice by which enchantment is enacted}

There are currently many possible ways of categorizing both religious embodiments as well as theoretical perspectives in the research of body and religion. For instance, Philip Mellor (2007) distinguishes six of the latter, all having slightly distinct epistemological and theoretical starting points, as well as empirical foci. His models for religion and embodiment are: the emotional, permeable, learning, mimetic, mindful and global body. Mellor's map is very useful for those who want to familiarize themselves with the richness of perspectives on how religion and embodiment can be seen to be penetrating one another.

Here I am concerned with at least three subtly distinguishable practices of enchanting bodies that I think I can identify in the Western world today. These ideal typical practices of embodiment also resonate with my own research interests in religion and the body over the last ten years. In the so-called 'real world', these ideal types can mix and juxtapose in many imaginative ways. I nevertheless suggest that they reveal some real difference, for instance, in the sense that the first one is the most explicit and relatively easy to discern, whereas the other two types of embodiment may be more implicit and subtle, both for the eye of the researcher as well as for the practitioner. I hope that this rough typology will be of some preliminary heuristic or analytical value when looking at the religious landscape today. In using the term practices I refer both to practices of argumentation, rhetoric and imagination, as well as to more concrete and physical practices of embodiment. I follow Jerome Carrette (2000) in understanding even beliefs as meaning-making practices, and thus I will not consider them as essentially or ontologically different from more embodied practices. Although some practices are more prominent in, for example, theological religiosity, others in popular religion (cf. e.g. Mitchell 
\& Mitchell 2008), they all have to do with bodies in their own ways. What they require is, of course, different concrete research methods.

For the purpose of this article I refer to these practices as follows: 1) moulding the surface of bodies; 2) exercising bodies; and 3) re-imagining bodies and minds/souls. All these types of practices can be looked at as ways of teaching and cultivating religiously meaningful and capable bodies (Asad 1997). In the first type of practice the pedagogy works rather from the realm of the visible into the invisible, and in the second and third ones in the contrary direction, that is, from less to more visible. In the following, I will briefly describe them. The latter two will, however, receive more emphasis as I consider them to form a slightly bigger challenge to the study of enchanted embodiments today. One reason behind this is that this is often also the form of religion that scholars take part in, with body-practices that we may nevertheless not always be fully aware of.

Moulding the surface of bodies. By this I mean practices of endowing the visible or, the 'outer' body with religious meaning by the means of dress/undress, head-dress, tattoos, piercings, purposefully visible ways of placing bodies in space, as well as means of behaving or gesticulating and so on. This is a concrete and impressive traditional, but also modern, way of constructing religious identity and distinctiveness. It is an elementary social means of boundary-making and it includes a variety of specific boundary-mechanisms by which people draw the always indefinite line denoting where their (religious) bodies end and the (profane) world begin (Vincett et al. 2008: 11). These mechanisms and operations do not remain on the surface of bodies but, to varying extents and degrees, reach below the body's surface and to the inside (the mindset or the consciousness) of the person. Similarly, they are not simply physical, but also argumentative and metaphorical meaning-making practices, as I show in my research Alaston ja puettu. Ruumiin ja uskonnon ääret (Naked and Dressed: The Limits of the Body and Religion, Utriainen 2006). Rosa's new Jewish habit, in Heller's novel, exemplifies this type of body practice fairly well.

In many of the studies of women's religiosity mentioned above, bodies are moulded by religiously changing their outlook, either for special ritual occasions, or also in day-to-day life. The North American witches in Salomonsen's (1999) study may strip naked as a special spiritual practice whereby they train their egos to become less preponderant. The initiation ritual to become fully a witch includes a moment of both blindness and nakedness - the meanings of which include trust and surrender. For some of the Muslim women studied both by Mahmood and Bracke, the covering of parts of their bodies bears the 
significance of both belonging to tradition as well as making a personal religious choice and stance towards society, life and the future. Thus marking and working with the borders and boundaries of bodies and also with the world may be an important and efficient religious practice.

The exercise of bodies. These are practices of argumentation as well as bodily techniques whereby embodiments are crafted and constructed from the 'inside out', for instance from religiously or spiritually exercising and cultivating bodies without necessarily marking this clearly on the surface of the body. This would contain some of today's popular exercises, such as yoga or meditation. Also, practices of putting bodies in contact with healing forces and energies (as Salomonsen's and McPherson's studies show), and empowering or resourcing them with the contact of supernatural beings, transcendent silence and emptiness, and so on, can be seen to belong to this category of body practice. These kinds of often, but not necessarily always eastern-inspired practices of crafting bodies from the inside out are becoming increasingly popular today, and people participate in them with differing degrees of orderliness, commitment and seriousness.

Also the life of the Catholic postulants which Rebecca L. Lester's study describes consists of a detailed and many-phased preparation programme by which they learn to take part in the complexities of modernity. A big part of this preparation could be seen as resourcing the future nun who will work in society among the poor, with the power and authority coming from her religion. Moreover, this resourcing is intimately tied to the affective and embodied condition of being human, Mexican and gendered. The postulants work with their bodily and cultural emotions and (erotic and other) desires and learn to cultivate their young modern female bodies as the bodies of God's handmaidens.

Re-imagining bodies and minds/souls. By this I mean practices that take place within the secular/profane sphere, whereby bodies are imagined and conceptualized in such ways that are different from and alternative to the Western secular scientific rationality. An example is contemporary health care: it includes spaces for and fragments of religious language and other practices that emphasize holism and spirituality. A lot of this could be seen as instances of de-differentiation if we understand it the way Grace Davie (2007: 224-7) does. By de-differentiation she encapsulates phenomena and events by which modernity turns actively and critically towards its own tendency to differentiate and segment spheres of life, knowledge and responsibility as well as corresponding aspects of the human being-in-the-world, and whereby it aims to bring these conceptual separations 'back' together. 'Holism' is often 
the name given to this activity and a way of re-conceptualization by its proponents.

A characteristic of practices of de-differentiation is that they often articulate and legitimate themselves critically against the phenomenon and discourses of modernity, secularization, and very often more specifically of medicalization, which is argued to have violently or wrongly segmented the human being and the human body, and the female body in particular, and thus alienated it from its supposed 'original', 'sacred' and 'natural' way of being-in-the-world. ${ }^{1}$ These acts and practices of de-differentiation can be found both in alternative well-being practices and discourses (such as Reiki in McPherson's study) as well as, and this is perhaps even more important in the post-secular vein, in official and 'secular' health care too. Thus health care contexts become influential in-between spaces. In practices of de-differentiation not only body and soul, but also other segments of life understood as having been driven apart (such as life and death, sacred and profane, self and other, transcendence and immanence, etc.) are actively stitched together. My research on how the language of de-differentiation, as well as the willingness to assume tasks of spiritual care has made its way into contemporary care of the dying, is one window to this aspect of contemporary embodied spiritual practices (Utriainen 2010).

In their own respective ways all these body-practices can be used to reconstruct the ways people relate to and act in their lives. If it is true that 'our view of life is dependent on how we operationalize our "bodily beings in the world" ' (Merleau-Ponty in Mellor \& Shilling 1997: 21), these embodied re-constructions, enacted through practices of training and cultivating religiously competent bodies (Asad 1997) are capable of bringing about lesser or greater transformations in views, attitudes and practices, as well as politics, of life and destiny.

These kinds of practices engage people as embodied subjects and agents of their own fragile destinies-subjects in the sense of being subjected to events, and agents in the sense of being capable of 'making things happen' (Meyer \& Jepperson 2000). Destiny, as sense of meaning and direction in one's life, can be understood either as a predetermined course of events (as fate/fortuna) or, and this is how I define it here, as the unfolding of one's life course with the help of human will and action, in which case action involves the body. Thus, 
transforming one's embodied way of orienting in life may, to an important extent, change or reorient one's future. When these transformations include a non-empirical, or divine authorization, legitimacy and motivation, they construct knowledge-structures and rationalities that can be seen as keyholes or windows to modernity's possible religious near futures.

My own research focuses very much on practices whereby people, mostly women, seek and actively make meaning and create destinies by and within healing or care-giving practices that include adjusting or re-adjusting body and soul. These practices are sometimes called 'holistic' and alternative spiritual practices by practitioners and users, which aim at re-constructing mind and body. This re-construction is done by combining secular (e.g. scientific and empirical) and more religious (non-empirical) forces and presences ${ }^{2}$ as resources in the attempts to bring out transformation or active engagement with the destinies of people in question.

\section{Implications for the study of religion today}

It is possible to look closely at what kinds of boundaries (i.e. identities and distinctions) are created by these practices, and also what kinds of 'divine', 'supernatural', 'transcendental' or other non-empirical forces or enchanting meaning-making devices circulate and are used in diverse practices. In addition to these two interpretational models, one could also have a close look at the pragmatic side of these practices and ask what is achieved by them; what kinds of agencies, futures and destinies people are envisioning and bringing about with these practices. This would entail asking how these body enchantments are fitted into people's everyday lives as well as into more secular contexts. What is done with them in these contacts with the more secular sphere and in various in-between spaces? I mean that scholars of religion could find their ways into various negotiations and linkings between secular rationalities and not so secular 'irrationalities' (or super-rationalities), and their multiple complex and creative combinations.

2 I have borrowed the notion 'presence' from Robert Orsi (2005). By this term he refers to the realness of otherworldly entities or forces which religious people live with. An interesting issue to study would be to observe how religious entities or forces vary from more concrete presences to metaphors, and what is people's tolerance and sensitivity towards strong, and even embodied religious presence in different social contexts. 
These contacts and in-between spaces are created within, as well as between, two territories; the secular and the religious. Such officially secular spaces as schools and hospitals may include pockets in which religious language or other practices can be found. Health care is a good example of a context of modern technical specialization and expertise, within which individuals sometimes have the sense of becoming merely objects of many distinct disciplines and knowledge. Thus, today it is possible to hear that in order to be able to sense coherence, wholeness and meaning, many people want to make space (both rhetorical and practical) where they bring together different spheres of knowledge, such as medical, spiritual, and so on, with respective parts or aspects of their own life in order to restore a lost 'whole'. If they do not want to step outside the modern world entirely (which is what only a minority of them wants) then they try to make the best of the two worlds. This may mean that they include some of the most valued parts of modernity, for instance, the atmosphere of the modern medical exactness, or scientific language, within various alternative or 'holistic' spaces (see, e.g., Besecke 2005 and Lynch 2007).

In this way, the best parts of modernity are often connected with magic and sense of purposefulness, the sense which means that there is something very special here for ' $m e$ '. What can also be combined, hoped for and attempted to be put (back) together by spiritual exercises, is the sense of being the agent of one's own life and destiny - the sense of being in charge, or at least, according to a more modest version, being capable of doing something to improve one's situation and future. At the same time, however, one may wish to be the $o b$ ject (or patient) of care, compassion, grace, healing forces or cosmic energies. People may want to have both choice and fate.

Furthermore, if these transformative practices of de-differentiation are motivated and legitimated by, as well as enacted within, such metaphysics and epistemologies that include a magical, transcendent or non-empirical something more, they may be welcomed to some degree as freeing people from experiences of being caught in an iron cage of instrumental rationality and empirical reasoning of the disenchanted world, or to provide a tool of criticism of that world. This feeling of relative freedom made possible by religion would be a very concrete example in today's social world of the transformative power of the imaginary, or, in other words, the 'power of as if', identified once by William James. 


\section{Bodily disturbances}

Thus, in the context of this article, post-secular is the name for the heuristic position in which the scholar of religion finds him/herself today; it is a position from which we can better distinguish various kinds of enchanted lives and bodies. I have described and hinted at some possible tasks and locations for research above. To close my text, I briefly want to comment on the implications this position might have on our more overall position with regard to our object of research.

In contrast to the relatively safe situation within the frame of secularization theories and the objectifying view they have offered within the category of religion, the scholar of religion can no longer comfortably assume that religion (including religious bodies) is an object which is neatly located 'outthere' in the world of others. ${ }^{3}$ Alternative spiritualities and their respective metaphysics and rationalities are intertwined in the contemporary culture in so many ways that they inevitably mix with the life-world of the scholar in one way or another, even if he/she would claim to be non-religious. If new spiritualities are notable varieties of today's popular or folk religiosity, they are that precisely by the virtue of being found in multiple spaces: in the articles of women's magazines, in well-being practices, seminars of workplaces, film and fiction, talk-shows as well as in commercials of health food, fitness centres, drugs and cosmetics.

According to Dick Houtman and Stef Aupers (2008), research has not so far paid enough attention to the subtle ways by which new spiritualities become socialized today. Likewise, the many ways in which religion is in the process of relocation, as well as the ways re-enchantment works, need more attention (cf. Partridge 2004). For instance, Anne-Christine Hornborg (2008) provides an analysis of the various ways in which the Swedish public sector is engaging alternative spirituality nowadays in, for example, supplementary education for teachers, or in helping young children with their psychosocial problems. Also in Finland, it is no longer necessary to go to special fairs organized for alternative spirituality. Instead, some of these courses are provided by community-run adult education centres. In 2010, these centres (aikuisopisto) provide, under the category of 'specialities' (cf. in England 'perservation. In the scholarship of religion this issue has been quite sensitively treated by Robert Orsi in his book Between Heaven and Earth: The Religious Worlds People Make and the Scholars Who Study Them (2005). 
sonal skills', Bowman 1999: 5) courses for instance on Reiki and astrology in Helsinki and Vantaa (capital area). Under the category 'physical exercise' one would find yoga, Chi Kung and Shakti-stretching. Scholars of religion very likely participate in practices that mediate and support some undercurrents of these contemporary hybrids of religion, and how they are learned and used.

Challenges will abound and flourish. Perhaps these challenges will also differ in cases of female and male researchers, since at least some of the subcultures and practices of these new folk religiosities pander differently to the different sexes. There are, for instance, what I call 'predominantly female spheres. This implies that some embodied practices, or body enchantments, are also gender-making practices in their own ways which articulate and modify mostly female bodies and their futures and destinies (cf. McGuire 2008: $158-83$ ). To a certain extent this should not be surprising at all; if secularization or dis-enchantment has different implications for women and men, why would not re-enchantment do that too (see Brereton \& Bendroth 2001, Woodhead 2008)?

Contemporary forms of religion are sometimes confusing to a female researcher, particularly if she is a feminist. While some body-enchantment practices may emphasize emancipatory female bodies, many others may look rather conservative. This bafflement may be felt strongly in research on women's religiosities nowadays, since religious agents are sometimes quite different from secular feminist emancipated agents in their choices about what to do with their bodies and how to construct embodied moral lives, agencies and destinies.

Alternatively, the female researcher may herself use some of the same resources or might be involved in similar practices, for instance in commercially organized or publicly available spiritual well-being practices, and thus intermingle with her own object of research. Furthermore, some feminists are already talking about a spiritual turn in feminism / feminist research (Braidotti 2008, Ahonen 2010). Would this mean that secularist feminist theories of religion are gradually giving way to more religion-friendly feminist theories that would, again in a new way, celebrate enchanted female bodies? ${ }^{4}$ How should the very often secular, or even secularist, feminist researchers then encounter this difference which is no longer such a clear-cut one? The colliant aspects of progressive spirituality, have introduced enchanted female bodies to the Western consciousness. However, they have sometimes been in a tense relationship with more secular feminist conceptions of religion and the body. 
sions of feminisms and religions carry implications concerning the embodied and political agency that are of great importance not only to the study of religions, but also to social sciences in general, as Saba Mahmood (2005: 195-9) emphasizes.

For some of us it may be puzzling to investigate something from which we do not have the historical or cultural distance to safeguard us and our analytic categories against. For others it may turn out to be convenient since it provides lots of possibilities for participatory observation. I also want to highlight the issue of ethics and ask if this kind of a situation could be taken to be not less but potentially more ethical, in some ways. By this I mean that from the postsecular position the researcher could no longer make herself the sublime and unaffected knower of religion and enchanted bodies. Instead, she would have to admit that she is also part of her quite unstable object of research, at least culturally if not religiously. And this ethical position immediately becomes a methodological one with the implication that we must train our analytic eye for quite new kinds of sensitivities and powers of resolution in order to see the diversity of embodied lives between illusion and disillusion.

\title{
References
}

\author{
Ahonen, Johanna \\ 2006 Spiritualistista feminismiä. Äiti Amma ja hänen suomalaiset seuraajansa. \\ Naistutkimus 19 (4): 29-44. \\ 2010 Nomadic Bodies, Transformative Spaces: Affective Encounters with Indian \\ Spirituality. In: Marianne Liljeström \& Susanna Paasonen (eds), Working \\ with Affect in Feminist Readings: Disturbing Differences; pp. 112-25. Abing- \\ don: Routledge.
}

Asad, Talal

1997 Remarks on the Anthropology of the Body. In: Sarah Coakley (ed.), Religion and the Body; pp. 42-52. Cambridge: Cambridge University Press.

\section{Besecke, Kelly}

2005 Seeing Invisible Religion: Religion as a Societal Conversation about Transcendent Meaning. Sociological Theory 23 (2): 179-96.

\section{Bowman, Marion}

1999 Healing in the Spiritual Marketplace: Consumers, Courses and Crentialism. Social Compass 46 (2): 181-9.

\section{Bracke, Sarah}

2008 Conjugating the Modern/Religious, Conceptualizing Female Religious Agency: Contours of a 'Post-secular' Conjuncture. Theory, Culture \& Society 25 (6): 51-67. 


\section{Braidotti, Rosi}

2008 In Spite of the Times: The Postsecular Turn in Feminism. Theory, Culture \& Society 25: 1-24.

\section{Brereton, Virginia Lieson \& Margaret Lamberts Bendroth}

2001 Secularization and Gender: An Historical Approach to Women and Religion in the Twentieth Century. Method \& Theory in the Study of Religion 13: 209-23.

\section{Cannell, Fenella}

2010 The Anthropology of Secularism. The Annual Review of Anthropology 39: 85-100.

\section{Carrette, Jeremy R.}

2000 Foucault and Religion: Spiritual Corporality and Political Spirituality. Lon-

\section{Davie, Grace} don: Routledge.

2007 Sociology of Religion. Thousand Oaks: Sage Publications.

\section{Giddens, Anthony}

1991 Modernity and Self-identity: Self and Society in the Late Modern Age. Cambridge: Polity Press.

\section{Heller, Zoë}

2008 The Believers. London: Penguin.

\section{Hornborg, Anne-Christine}

2008 Att återförtrolla det sekulariserade samhället. Är Sverige på väg in i Vattumannens tidsålder? Svensk Religionshistorisk Årsskrift 2006-2007: 33-59.

\section{Houtman, Dick \& Stef Aupers}

2008 The Spiritual Revolution and the New Age Gender Puzzle: The Sacralization of the Self in Late Modernity (1980-200o). In: Kristin Aune, Sonya Sharma \& Giselle Vincett (eds), Women and Religion in the West: Challenging Secularization; pp. 99-118. Hampshire: Ashgate.

\section{Hovi, Tuija}

2007 Usko ja kerronta. Arkitodellisuuden rakentuminen uskonliikkeessä. Turku: Turun yliopisto.

\section{Lester, Rebecca J.}

2005 Jesus in Our Wombs: Embodying Modernity in a Mexican Convent. Berkeley: University of California Press.

\section{Lynch, Gordon}

2007 The New Spirituality: An Introduction to Progressive Belief in the Twenty-first Century. London: I.B. Tauris.

\section{Mahmood, Saba}

2005 Politics of Piety: The Islamic Revival and the Feminist Subject. Princeton: Princeton University Press.

\section{McGuire, Meredith}

1988 Ritual Healing in Suburban America. New Brunswick: Rutgers University Press. 
2008 Faith and Practice in Everyday Life. Oxford: Oxford University Press.

\section{McPherson, Judith}

2008 Women and Reiki. Energetic/Holistic Healing in Practice. London: Equinox.

\section{Mellor, Philip}

2007 Embodiment, Emotion and Religious Experience: Religion, Culture and the Charismatic Body. In: James A. Beckford \& N. J. Demerath, III (eds), The Sage Handbook of the Sociology of Religion; pp. 587-607. London: Sage Publications.

\section{Mellor, Philip A. \& Chris Shilling}

1997 Re-forming the Body: Religion, Community and Modernity. London: Sage Publications.

\section{Meyer, John W. \& Ronald L. Jepperson}

2000 The "Actors" of Modern Society: The Cultural Construction of Social Agency. Sociological Theory 18 (1): 100-20.

\section{Mitchell, Jon P. \& Hildi J. Mitchell}

2008 Embodiment and Immanence in Catholicism and Mormonism. Social Analysis $52(1): 79-94$.

\section{Orsi, Robert}

2005 Between Heaven and Earth: The Religious Worlds People Make and the Scholars Who Study Them. Princeton: Princeton University Press.

\section{Partridge, Chris}

2004 The Re-Enchantment of the West. Vol. 1. London: Continuum.

Salomonsen, Jone

1999 Enchanted Feminism: The Reclaiming Witches of San Francisco. London: Routledge.

\section{Sebold, Alice}

2009 The Lovely Bones. Boston: Little Brown and Company.

Taylor, Charles

2002 Varieties of Religion Today: William James Revisited. Cambridge: Harvard University Press.

\section{Utriainen, Terhi}

2006 Alaston ja puettu. Ruumiin ja uskonnon ääret. Tampere: Vastapaino.

2010 Agents of De-differentiation: Women Care-givers for the Dying in Finland. Journal of Contemporary Religion 25 (3): 437-51.

Vincett, Giselle, Sonya Sharma \& Kristin Aune

2008 Introduction. Women, Religion and Secularization: One Size Does Not Fit All. In: Kristin Aune, Sonya Sharma \& Giselle Vincett (eds), Women and Religion in the West: Challenging Secularization; pp. 1-19. Hampshire: Ashgate.

\section{Woodhead, Linda}

2008 'Because I'm Worth It': Religion and Women's Changing Lives in the West. In: Kristin Aune, Sonya Sharma \& Giselle Vincett (eds), Women and Religion in the West: Challenging Secularization; pp. 148-61. Hampshire: Ashgate. 